\title{
Evaluasi Penerapan Patient Safety dalam Pemberian Obat di Wilayah Kerja Puskesmas Kasihan II Kabupaten Bantul Yogyakarta
}

\author{
Anggi Napida Anggraini ${ }^{1}$,Fatma Siti Fatimah² \\ 1,2 Sekolah Tinggi Ilmu Kesehatan Alma Ata Yogyakarta \\ Jalan Ringroad Barat Daya No 1 Tamantirto, Kasihan, Bantul, Yogyakarta
}

\begin{abstract}
Abstrak
Keselamatan pasien adalah tidak adanya bahaya yang ditimbulkan yang dapat dicegah kepada pasien selama proses perawatan kesehatan. Salah satu indikator pada keselamatan pasien pada praktik farmasi adalah prinsip pemberian obat, penelitian ini menggunakan 6 prinsip pemberian obat. Penelitian ini menggunakan mix method, yang dilakukan di Puskesmas Kasihan II pada tanggal 5-28 Oktober 2015. Responden dalam penelitian ini, 2 orang apoteker, pasien dan kepala Puskesmas. Penerapan patient safety dalam pemberian obat berdasarkan 6 prinsip benar, menunjukkan 100\% prinsip benar Rute dan kadaluarsa, 78,5\% prinsip benar pasien, 63,7\% benar obat, 94,1\% benar dosis dan 25,5\% benar informasi. Berdasarkan analisis kualitatif, penerapan patient safety berdasarkan 6 prinsip pemberian obat didapatkan hasil, petugas mengecek identitas pasien, menyesuaikan dosis, menyesuaikan resep, memberikan informasi terkait obat yang diberikan kepada pasien. Masalah yang didapat dari penerapan 6 prinsip pemberian obat adalah terdapat 6 resep yang diberikan lebih dari dosis yang sebenarnya, tidak tersedianya tempat untuk menyimpan obat-obatan yang telah kadaluarsa, ketidakseimbangan antara apoteker dengan jumlah pasien. Saran dan harapan yang dapat diberikan adalah penambahan SDM pada apotek dan menyediakan ruangan untuk menyimpan obat-obatan yang telah kadaluarsa.
\end{abstract}

Kata Kunci: keselamatan pasien, 6 prinsip pemberian obat

\section{Evaluation of Patient Safety Application in Administering Drugs in Area of Primary Health Care Bantul, Yogyakarta}

\begin{abstract}
Patient safety is the absence of the danger posed to the patient can be prevented during the process of health care. One of the indicators of patient safety in pharmacy practice is the principle of the drug, this using the 6 principles of drug administration. Research using a mix method, this research occured in Puskesmas of Kasihan II on October 5-28, 2015. The respondents in this study were 2 pharmacists, patient and the head of the health center. Application of patient safety in drug delivery based on 6 principles correctly, showing $100 \%$ true with principles and expired, 78,5\% true principles patient, 63,7\% right drug, right dose of $94,1 \%$ and $25,5 \%$ correct information. Based on qualitative analysis, the application of patient safety based on 6 principles of drug administration were obtained, the officer checks the identity of the patient, adjust the dose, adjusting the recipe, provide drug-related information provided to the patient. Problems derived from the application of the 6 principles of drug delivery was 6 reciper identified were given much more than the actual dose, no places to store drugs that have expired, an imbalance between the number of patients pharmacist. Advice and hope that can be given is the addition of human resources in pharmacy and provide room for storing medicines that have expired.
\end{abstract}

Keywords: patient safety, 6 principle of the drug

Info Artikel:

Artikel dikirim pada 7 Oktober 2015

Artikel diterima pada 7 Oktober 2015 


\section{PENDAHULUAN}

Keselamatan pasien adalah pelayanan yang tidak menciderai atau merugikan pasien, dengan demikian pelayanan yang mengandung unsur kesalahan namun tidak sampai merugikan pasien (menciderai fisik, finansial) atau KNC (Kejadian Nyaris Cedera) masih ditoleransi(1). Sampai saat ini masalah keselamatan pasien Rumah Sakit masih menjadi masalah global, Joint Commission International $(\mathrm{JCl})$ \& world health organitation (WHO) melaporkan beberapa negara terdapat $70 \%$ kejadian kesalahan pengobatan meskipun, $\mathrm{JCl}$ \& WHO mengeluarkan "Nine Life-Saving Patient Safety Solutions" atau 9 solusi keselamatan pasien. Kenyataannya, permasalahan keselamatan pasien masih banyak terjadi termasuk di Indonesia $(2,3)$.

Berdasarkan DepKes dan Permenkes No. 1691 tahun 2011 tentang keselamatan pasien, menyebutkan jenis-jenis keselamatan pasien antara lain: 3-16\% di Rumah sakit terjadi antara lain: kejadian tidak diinginkan (KTD) (advere event), Cahyono menjelaskan KTD dampak yang dirasakan pasien menyebabkan kerugian pasien yang didapat diluar penyakit yang diderita dikarenakan cidera medis, kejadian nyaris cidera (KNC) (near miss), kejadian potensial cidera (KPC), dan kejadian sentinel, Cahyono menjelaskan insiden keselamatan pasien sentinel terjadi di Amerika sebanyak 100.000 pasien meninggal karena cidera medis yang seharusnya bisa dicegah $(1,4,5)$.

DepKes melaporkan insiden keselamatan pasien yang paling banyak terjadi di Indonesia adalah kesalahan pemberian obat(4). Pelaksanaan pemberian obat pelaksaan pemberian obat harus menerapkan prinsip 5 benar untuk menghindari insiden keselamatan pasien. American Nursing Association's (ANA), Potter \& Perry, Berman et al menjelaskan prinsip-prinsip pemberian obat antara lain: yang pertama adalah benar obat, benar obat merupakan obat yang diberikan kepada pasien sesuai dengan resep dari dokter. Prinsip pemberian obat yang ke dua adalah benar dosis, dosis diberikan sesuai dengan karakteristik pasien maksudnya sesuai hasil perhitungan dan jenis obatnya dalam jumlah tertentu. Benar jalur atau rute, benar rute merupakan pemberian obat sesuai jalur yang diprogramkan dan dipastikan bahwa rute tersebut aman sesuai untuk pasien. Benar pasien, benar pasien dapat dipastikan dengan cara memastikan gelang indentifikasi sesuai dengan prosedur yang berlaku, benar expired atau kadaluwarsa lebih memperhatikan tanggal kadaluwarsa dan selalu rutin dalam memeriksa tanggal kadaluwarsa secara berkala. Terakhir adalah benar informasi, perawat memberikan informasi yang benar tentang obat untuk menghindari kesalahan dalam menerima obat, memberikan informasi cara kerja dan efek samping obat yang diberikan $(6,7)$.

Keselamatan pasien bisa terjamin dengan adanya upaya yang dilakukan dari semua pihak yang terlibat dalam pelayanan kesehatan khususnya yang berhubungan langsung dengan pasien. Untuk mengetahui terjaminnya keselamatan pasien maka perlu dilakukan penelitian untuk mengetahui pelaksanaan keselamatan pasien terutama berhubungan dengan pemberian obat telah dilakukan di Puskesmas Kasihan II. Berdasarkan uraian diatas maka rumusan masalah penelitian ini adalah untuk melihat bagaimanakah evaluasi penerapan patient safety dalam pemberian obat di Puskesmas Kasihan II, selain itu masalah dan hambatan penerapan patient safety dalam pemberian obat di Puskesmas Kasihan II, serta saran dan harapan dalam penerapan patient safety dalam pemberian obat di Puskesmas Kasihan II.

\section{BAHAN DAN METODE}

Jenis penelitian ini merupakan penelitian Mix Method yaitu penelitian kuantitatif dengan rancangan cross sectional survey dan penelitian kualitatif dengan rancangan studi kasus. Penelitian ini dilakukan di Puskesmas Kasihan II pada bulan 5-28 Oktober 2015. Responden dalam wawancara mendalam ada 4 orang yaitu, Apoteker yang terlibat langsung melayani pasien serta semua tindakan pemberian obat yang dilaksanakan di Puskesmas Kasihan II berjumlah 2 orang, pasien puskesmas berjumlah 1 orang dan Kepala Puskesmas Kasihan II berjumlah 1 orang. Teknik pengumpulan data menggunakan ceklis observasi dan panduan wawancara terstruktur, kemudian data tersebut di analisis menggunakan analisis kuantitatif dan analisis konten untuk data kualitatif.

\section{HASIL DAN BAHASAN}

Hasil penelitian didalam naskah ini, disajikan dalam bentuk kuantitaif dan kualitatif yang disertai dengan uraian, serta akan diurutkan sesuai dengan tujuan penelitian. 


\section{Observasi Pemberian Obat (Kuantitatif)}

Hasil penelitian yang dilakukan di Puskesmas Kasihan II untuk observasi pemberian obat secara langsung ditampilkan dalam bentuk Tabel 1.

Tabel 1. Distribusi dan Frekuensi Pemberian Obat di Puskesmas Kasihan II

\begin{tabular}{lcccc}
\hline \multirow{2}{*}{ Prinsip Benar } & \multicolumn{2}{c}{ Dilakukan } & \multicolumn{2}{c}{ Tidak Dilakukan } \\
\cline { 2 - 5 } & $\mathbf{f}$ & $\%$ & $\mathbf{f}$ & $\%$ \\
\hline Pasien & 80 & 78,4 & 22 & 21,6 \\
Rute & 102 & 100 & 0 & 0 \\
Obat & 65 & 63,7 & 37 & 36,3 \\
Dosis & 96 & 94,1 & 6 & 5,9 \\
Informasi & 26 & 25,5 & 76 & 74,5 \\
Kadaluwarsa & 102 & 100 & 0 & 0 \\
\hline
\end{tabular}

Tabel 1 menunjukkan bahwa penerapan patient safety dalam pemberian obat berdasarkan 6 prinsip benar menunjukkan $100 \%$ prinsip benar rute dan kadaluwarsa telah dilaksanakan dan $78,5 \%$ prinsip benar pasien, $63,7 \%$ benar obat, $94,1 \%$ benar dosis dan $25,5 \%$ benar informasi telah dilakukan pada Puskesmas Kasihan II.

\section{Hasil Wawancara (Kualitatif)}

Evaluasi penerapan patient safety pemberian obat dilakukan dengan menggunakan metode wawancara mendalam (Indepth Interview) sebagai sumber pencarian data pokok dalam penelitian. Wawancara mendalam dilakukan dengan berdasarkan pedoman wawancara terstruktur. Penyajian hasil wawancara dalam naskah ini, akan disajikan sesuai dengan tujuan penelitian.

\section{Evaluasi Penerapan Patient Safety dalam Pemberian Obat di Puskesmas Kasihan II}

Berdasarkan hasil koding wawancara kepada 4 responden di Puskesmas Kasihan II dapat dilihat bahwa penerapan patient safety dalam pemberian obat di Puskesmas Kasihan II sudah berjalan dengan baik, petugas sudah menerapkan prinsip 6 benar dalam pemberian obat, antara lain benar pasien, benar obat, benar jalur, benar dosis, benar kadaluarsa, dan benar informasi. Pada komponen prinsip 6 benar pemberian obat, yang pertama adalah benar obat. Hasil evaluasi yang didapat adalah dari 2 responden, petugas memberikan obat sesuai order dokter yang tertera dalam resep, seluruh responden yang dievaluasi menyatakan bahwa dapat membaca resep dengan baik atau apabila ada ketidak jelasan pada resep, petugas akan mengkonfirmasi langsung pada dokter yang bersangkutan yang memberi resep. Pada komponen benar obat, 2 responden (R2 dan R3) menyatakan selalu memastikan nama obat sesuai dengan label yang tertera pada tempat obat, kemudian responden menyesuaikan obat yang ada diresep, sehingga pemberian dapat terpastikan benar.

Komponen yang kedua adalah benar dosis, berdasarkan hasil wawancara pada 2 responden (R2 dan R3) terkait dengan benar dosis didapatkan hasil, responden R3 selalu memberikan dosis yang sesuai dengan sesuai dengan resep dokter, sedangkan pada responden $\mathrm{R} 2$, peneliti menemukan perbedaan hasil, berdasarkan observasi secara langsung yang dilakukan oleh peneliti yang ikut terlibat dalam menyiapkan obat-obatan untuk pasien, terdapat 6 resep yang dilebihkan dosisnya, antara lain untuk sejenis vitamin, CTM, Analgesic dan Anti Inflamasi. Konfirmasi yang dilakukan peneliti pada R2 dalam wawancara, responden R2 menyatakan untuk beberapa jenis obat diberikan dengan dosis lebih dikarenakan persediaan obat yang berlebih dan ada beberapa jenis obat diberikan dengan dosis yang kurang dengan alasan penyediaan yang sudah disiapkan, hal ini dikuatkan dengan hasil deskriptif wawancara kepada R2 yaitu:

"Oh itu kan obat-obatnya banyak stoknya
mbak jadi gapapa lah klo dilebihin
ngasihnya. Klo kurang gitu juga gapapa,
biasanya karna sediaannya yang sudah
kita kasih etiket itu biasanya kita sama
ratakan gitu, soalnya disini kan dokternya
ada dua dan keduanya ini beda-beda
ngasih dosisnya, ada yang ngasih 10
ada yang ngasih 6, lah itu kan kita
nyediainnya yg dikasih etiket kan yang
10, jadi gapapa."

Hal ini tidak tepat karena dapat menyebabkan hal-hal yang dapat membahayakan keselamatan pasien, dengan melihat latar belakang pendidikan masyarakat yang berobat di puskesmas beragam, sehingga tidak menutup kemungkinan dapat terjadinya penyalahgunaan obat-obatan. Sesuai dengan hasil observasi Tabel 1 sebanyak 5,9\% yang belum menerapkan benar dosis. Pasien yang mendapatkan obat berlebih atau kurang akan menyebabkan respon obat menjadi tidak maksimal 
bahkan bisa menimbulkan resistensi pada pemberian antibiotik melebihi dosis yang dianjurkan(5). Hal serupa didukung oleh pernyataan R1, yaitu:

"Seharusnya gak boleh seperti itu, setiap apoteker paham hal itu mbak. Ya ada kemungkinan untuk penyalahgunaan obat-obatan. Tapi walopun stok obat berlebih kan tidak seharusnya begitu. Tetap tidak diperbolehkan, apalagi untuk sejenis antibiotic dan anti inflamasi itu kan cukup berbahaya"

R1 menilai, melebihkan dosis atau mengurangkan dosis merupakan tindakan yang tidak dibenarkan, sebab akan memungkinkan terjadinya penyalahgunaan obat-obatan, R1 menilai bahwa seorang apoteker memahami hal tersebut yang juga berkaitan dengan etika profesi apoteker, sekalipun persediaan obat-obatan tersebut didalam Puskesmas termasuk banyak. Hal ini sesuai dengan Benar dosis menurut Institude for Safety Medication Practise (ISMP)(6), menyebutkan petugas harus memiliki ketrampilan memotong obat untuk menghindari kesalahan dosis obat. Dosis diberikan sesuai dengan karakteristik pasien maksudnya sesuai hasil perhitungan dan jenis obatnya dalam jumlah tertentu. Petugas harus mampu melakukan perhitungan terhadap kalkulasi obat yang dibutuhkan pasien.

Komponen 6 benar prinsip pemberian obat yang ke 3 adalah, benar rute dan alur pemberian obat. Berdasarkan hasil wawancara pada ke 2 responden ( $R 2$ dan $R 3$ ) didapatkan hasil, responden menyatakan memastikan rute pemberian obat dan menginformasikan ke pasien terkait dengan hal tersebut. Hal ini sesuai dengan pemaparan dalam The Joint Commission (TJC)(6), Benar rute merupakan pemberian obat sesuai jalur yang diprogramkan dan dipastikan bahwa rute tersebut aman sesuai untuk pasien. Prinsip 6 benar yang ke 4 adalah benar pasien, berdasarkan hasil wawancara yang dilakukan oleh peneliti, didapatkan hasil seluruh responden yaitu R2 dan R3 menyatakan bahwa selalu memastikan identitas pasien berupa nama dan alamat pasien, hal ini dilakukan setiap akan memberikan obat pada pasien. Baik itu disesuaikan dengan resep dan juga ditanyakan langsung kepada pasien yang bersangkutan. Komponen yang ke lima adalah benar kadaluarsa, peneliti selain melakukan wawancara, juga melakukan observasi secara langsung. Berdasarkan hasil wawancara ke 2 responden yaitu R2 dan R3 menyatakan bahwa, responden memastikan tanggal kadaluarsa pada obat sebelum obat-obatan tersebut dikeluarkan dari gudang dan diletakkan pada tempat obat, R3 menyatakan bahwa pengecekan dilakukan secara berkala dalam 1 bulan, dilakukan 1 kali pengecekan. Sedangkan penuturan dari responden $\mathrm{R} 1$, pengecekan kadaluarsa obat juga dilakukan oleh DINKES dalam 3 bulan dilakukan 1 kali pengecekan. Berdasarkan observasi yang didapatkan oleh peneliti, obat-obatan yang telah kadaluarsa diletakkan tersendiri didalam kardus dan diletakkan didalam gudang penyimpanan persediaan obat, hal ini dinilai kurang memadai dikarenakan letak yang berdekatan atau dalam 1 ruangan dengan obat-obatan yang masih digunakan dapat terjadi kesalahan dalam pengambilan obat dalam persediaan obat. Komponen prinsip 6 benar yang terakhir adalah, Benar Informasi. Pada hasil wawancara ini, responden R2 dan R3 menyatakan bahwa, telah melakukannya dengan baik, antara lain yaitu petugas memberikan penjelasan rute pemberian obat, terutama pada obat-obatan dengan jalur selain oral seperti: suppositorial, tetes telinga, dan salep. Selain memberitahukan rute/jalur obat petugas juga memberitahu cara kerja/fungsi obat, namun menurut responden $\mathrm{R} 4$, petugas tidak memberitahukan pada seluruh jenis obat, hal ini dijelaskan dalam kutipan wawancara:

\section{"Kalo nama obat kayaknya ngga semua ya mba, tapi menjelaskan misal obat ini untuk panas, obat ini vitamin, obat ini untuk antibiotic harus habis, gitu mbak."}

Responden R2 dan R3 menyatakan bahwa, selalu memberitakukan efek samping dari obat kepada pasien. Evaluasi lainnya diluar dari 6 prinsip pemberian obat, didapatkan hasil antara lain, R1 dan R3 menyatakan bahwa SOP pemberian obat dan patient safety ada namun tidak ditempel di dinding. Selain itu, kepala puskesmas meninjau kinerja petugas apotek, namun tidak dilakukan secara berkala namun hanya sesekali saja, dikarenakan evaluasi kinerja apoteker dilakukan 3 bulan sekali oleh DINKES. Selain yang berkaitan dengan SOP dan kinerja apoteker, Puskesmas Kasihan II merupakan instansi yang kerap dijadikan lahan praktik untuk 
mahasiswa, kerja sama dilakukan oleh beberapa kampus dengan Puskesmas Kasihan II, menurut Responden R1 sebelum mahasiswa melakukan praktik, pihak kampus dan pihak Puskesmas, melakukan sosialisasi dan orientasi pada mahasiswa yang akan praktek di Puskesmas.

\section{Evaluasi Masalah dan Hambatan Penerapan Patient Safety dalam Pemberian Obat}

\section{Manajemen}

Berdasarkan hasil wawancara terkait dengan masalah dan hambatan yang berkaitan dengan manajemen, antara lain adalah: SOP tidak ditempel di ruang apotek dan alur pemberian obat tidak semua ditempel dinding puskesmas. Berdasarkan dari 3 responden yaitu R1, R2 dan R3 menyatakan bahwa SOP yang ada tidak ditempel di dinding apotek Puskesmas, R1 dan R3 menyatakan bahwa SOP yang ada disimpan dan tidak di tempel. Berdasarkan observasi peneliti pada alur pemberian obat, di lingkungan Puskesmas sudah ditempel, Alur pemberian obat yang ditempel dilihat lebih efektif karena selain petugas dapat membaca, pasien juga dapat membaca secara langsung terkait dengan alur pemberian obat sehingga dapat mengefesienkan waktu ketika pemberian obat. Semua tenaga kefarmasian di Puskesmas melaksanakan pelayanan kefarmasian berdasarkan Standar Prosedur Operasional (SPO) yang dibuat secara tertulis, disusun oleh kepala ruang farmasi, dan ditetapkan oleh kepala puskesmas. SPO tersebut diletakkan ditempat yang mudah dilihat. Jenis SPO yang dibuat sesuai dengan kebutuhan pelayanan yang dilakukan pada puskesmas yang bersangkutan. Isi dari PERMENKES tersebut menjelaskan bahwa, standar operating prosedur mutlak ada dalam suatu puskesmas yang menyelenggarakan instansi kefarmasian dan diletakkan pada tempat yang mudah lihat oleh orang lain.

\section{Prinsip Pemberian Obat}

Pada kategori 6 prinsip pemberian obat, hasil wawancara terkait dengan masalah dan hambatan yang didapat adalah Pemberian obat secara berlebih memungkinkan terjadinya penyalahgunaan obat, hal ini telah disampaikan oleh responden R1 bahwa pemberian obat dengan dosis yang dilebihkan atau dikurangkan tidak diperbolehkan meskipun didalam suatu puskesmas tersebut persediaan obat dalam jumlah yang besar. Obat-obatan yang diberikan secara berlebih, berdasarkan observasi peneliti, obat-obatan yang diberikan dengan dosis berlebih yaitu antibiotic, anti inflamasi, analgesic, CTM. Label nama obat yang ditempel diloker sediaan obat baru dibuat 1 bulan yang lalu, menurut responden R2. Hal ini terkutip dalam:

"Ini kan disini baru karna ada saya aja
mbak baru saya buat label-label nya yg
di kotak obatnya. Kemarin-kemarin nggak
ada, buat memudahkan kerja juga kalo
mau nyari obat"

Menurut responden R2, berdasarkan kutipan wawancara diatas, label-label yang terdapat pada loker tempat obat, baru dibuat 1 bulan yang lalu, sebelumnya belum ada label nama-nama obat yang tertempel di loker tersebut. Pemberian labellabel nama obat di loker tersebut dinilai R2 dapat memudahkan proses pencarian obat-obatan, lebih tertata dengan rapih dan memudahkan kerja apoteker dalam penyiapan dan pemberian obat. Menurut responden R4, Tidak semua nama obat di jelaskan oleh petugas dan tidak semua dijelaskan efek samping dari obat-obatan yang diberikan oleh apoteker. Hal inii sesuai dengan kutipan wawancara berikut:

"Kalo nama obat kayaknya ngga semua
ya mba, tapi menjelaskan misal obat
ini untuk panas, obat ini vitamin, obat
ini untuk antibiotic harus habis, gitu
mbak"

Berdasarkan kutipan diatas peneliti menilai perlu adanya evaluasi terkait dengan pemberian informasi secara lengkap. Pada obat-obatan yang repack, tidak tertera tanggal kadaluarsanya, menurut responden $\mathrm{R} 4$ tidak adanya nama obat pada kemasan repack. Hal ini mengakibatkan ketidaktahuan pasien dengan tanggal kadaluarsa dari obat tersebut sehingga penggunaan obat-obatan dapat terjadi kesalahan. Berdasarkan observasi peneliti, pada kemasan obat-obatan yang repack, tidak tertera nama obat, yang tertera hanya frekuensi pemakaian obat, misal: $2 \times 1$ hari.

\section{Sarana dan Prasarana}

Berdasarkan hasil wawancara terkait dengan masalah dan hambatan, didapatkan dibidang sarana 
dan prasarana yaitu, tidak ada tempat khusus untuk menyimpan obat-obatan yang kadaluwarsa. Berdasarkan hasil observasi yang dilakukan oleh peneliti, tidak adanya tempat khusus untuk menampung obat-obatan yang telah kadaluwarsa, obat-obatan yang telah kadaluarsa diletakkan di dalam kardus dan diletakkan berdekatan dengan persediaan obat yang masih layak pakai, namun masih dalam satu gudang penyimpanan. Selain berdasarkan hasil observasi dari peneliti, hal ini dikuatkan juga oleh pernyataan responden R2 yaitu:

"Klo obat-obat kadaluarsa dipisah mbak, tapi cuma dimasukkan ke kerdus, tetap dalam ruangan yg sama dengan obatobatan yang masih bagus"

Ruang penyimpanan obat dan bahan medis habis pakai termasuk sarana dan orasarana yang harus diperhatikan, ruangan penyimpanan tersebut harus memperhatikan kondisi sanitasi, temperatur, kelembaban, ventilasi, pemisahan untuk menjamin mutu produk dan keamanan petugas. Selain itu juga memungkinkan masuknya cahaya yang cukup. Ruang penyimpanan perlu dilengkapi dengan rak/ lemari obat, pendingin ruangan, lemari penyimpanan khusus untuk obat-obatan narkotika dan psikotropika, lemari penyimpanan obat khusus, pengukur suhu. Istilah Ruangan yang dijelaskan di atas tidak harus dijelaskan sebagai wujud ruangan secara fisik, namun lebih kepada fungsi yang dilakukan. Bila memungkinkan, setiap fungsi tersebut disediakan ruangan secara tersendiri, jika tidak, maka dapat digabung kan lebih dari 1 fungsi, namun harus terdapat pemisahan yang jelas antar fungsi terlebih untuk pengaturan ruang obat-obatan yang telah tidak terpakai atau kedaluwarsa(8).

\section{Sumber Daya Manusia}

Masalah terkait dengan sumber daya manusia yang ditemukan dari pemaparan responden adalah petugas nonmedis (kasir) membantu apoteker dalam menyiapkan dan memberikan obat, jumlah petugas apotek tidak sebanding dengan jumlah pasien, tidak ada asisten apoteker yang membantu saat bertugas dan kinerja apoteker kurang maksimal. Penyelenggaraan pelayanan kefarmasian di Puskesmas minimal harus dilaksanakan oleh 1 orang tenaga apoteker sebagai penanggung jawab yang dapat dibantu oleh tenaga teknis kefarmasian sesuai kebutuhan, praktik kefarmasian yang dibantu oleh tenaga nonmedis tidak sesuai dengan perundang-undangan, karena tenaga non medis tidak memiliki kompetensi dalam melaksanakan praktik kefarmasian. Semua tenaga kefarmasian harus memiliki STR dan surat izin praktik untuk melaksanakan pelayanan kefarmasian di fasilitas pelayanan kesehatan termasuk Puskesmas, sesuai dengan peraturan perundang-undangan ${ }^{6}$. Hal ini tidak sesuai dengan hasil wawancara yang didapatkan, menurut responden R1, R2, dan R3, petugas nonmedis (kasir) juga membantu apoteker dalam menyiapkan dan memberikan obat.

Jumlah kebutuhan apoteker di puskesmas, dihitung berdasarkan rasio kunjungan pasien, baik rawat inap maupun rawat jalan. Serta memperhatikan pengembangan Puskesmas. Rasio untuk menentukan jumlah apoteker di Puskesmas adalah 1 apoteker untuk 50 pasien per hari(5). Angka kunjungan pasien di Puskesmas Kasihan II perharinya mencapai 100 pasien, dan tenaga kefarmasian di apotek tersebut hanya 1 orang apoteker. Adanya hal tersebut dapat mengakibatkan kinerja apoteker yang kurang maksimal, dapat disebabkan faktor kelelahan sehingga dapat mengakibatkan terjadinya kelalaian dalam melakukan praktik kefarmasian.

Masalah dan hambatan dalam bidang SDM, ditemukan dari pemaparan responden adalah petugas nonmedis (kasir) membantu apoteker dalam menyiapkan dan memberikan obat, jumlah petugas apotek tidak sebanding dengan jumlah pasien, tidak ada asisten apoteker yang membantu saat bertugas dan kinerja apoteker kurang maksimal. adanya hal tersebut dapat mengakibatkan kinerja apoteker yang kurang maksimal, dapat disebabkan factor kelelahan sehingga dapat mengakibatkan terjadinya kelalaian dalam melakukan praktik kefarmasian.

\section{Saran dan Harapan dari Penerapan Patient Safety Pemberian Obat}

Saran dan harapan yang dapat ditujukan pada Puskesmas, untuk kategori manajemen saran dan harapan adalah sistem penataan resep diperbaiki. Hal ini berkaitan dengan pendokumentasian arsip kefarmasian. Ruang arsip memerlukan ruangan khusus yang memadai dan aman untuk memelihara dan menyimpan dokumen dalam rangka untuk menjamin penyimpanan sesuai hukum, aturan, persyaratan, dan teknik manajemen yang baik(8). 
Pengadaan komputer yang terintegrasi dengan system, system informasi yang terintegrasi memudahkan petugas apoteker untuk proses pendokumentasian sehingga informasi dapat di akses oleh semua pengguna system informasi di apotek di Kasihan II.

Perlunya penambahan SDM dinilai penting karena melihat beban kerja apoteker, yang seharusnya sesuai dengan PERMENKES RI nomor 31 tahun 2014 dimana rasio untuk 1 apoteker menangani 50 pasien(8).

\section{SIMPULAN DAN SARAN}

Berdasarkan hasil penelitian maka dapat disimpulkan beberapa hal sebagai jawaban atas permasalahan yang ada di dalam penelitian ini, yaitu: penerapan patient safety dalam pemberian obat berdasarkan 6 prinsip benar menunjukkan 100\% prinsip benar rute dan kadaluarsa telah dilaksanakan. dan $78,5 \%$ prinsip benar pasien, $63,7 \%$ benar obat, $94,1 \%$ benar dosis dan $25,5 \%$ benar informasi telah dilakukan pada Puskesmas Kasihan II.

Berdasarkan hasil wawancara, evaluasi penerapan patient safety dikategorikan 2 kelompok, pada bidang manajemen berkaitan dengan SOP yang telah ada namun tidak ditempel di ruangan, dan evaluasi terhadap 6 prinsip pemberian obat sudah berjalan dengan baik meski terdapat beberapa masalah yang masih belum sesuai dengan prosedur dan undang-undang yang ada, dalam hal ini terkait dengan penempatan obat-obatan yang telah kadaluarsa yang masih belum terkelola dengan baik, serta tidak sesuainya rasio perbandingan antara Apoteker dengan pasien sehingga kinerja kurang maksimal.

Saran dan harapan antara lain adanya penataan manajemen apotek yang lebih terkelola, termasuk adanya sarana dan prasarana komputerisasi yang terintegrasi dengan system, serta penambahan jumlah SDM apoteker atau asisten apoteker. Terkait dengan manajemen, antara lain adalah sistem penataan resep pada bulan yang telah lalu dapat tertata dengan baik. Pengadaan komputer diruangan apotek yang terintegrasi dengan system. Tersedianya ruang tersendiri untuk penyimpanan obat-obat kadaluarsa, serta adanya penambahan SDM di ruang apotek.

\section{RUJUKAN}

1. Cahyono. Membangun budaya keselamatan pasien dalam praktek kedokteran. Yogyakarta: Kanisius; 2008.

2. Joint Commission International Acreditation. Standart for Hospital. 4th ed. Penj: Meitasari T,Nicole B. Ed: Grace F, Sitomurung, Donda SS, Jeffry O, Anastina T, Elisa T, Jakarta: PT. Gramedia; 2011.

3. World Health Organization \& Joint Comission International. Communication during patient handovers [internet]. 2007. Available from: http://www. who.int/patientsafety/solutions/patientsafety/ PS-Solution3.pdf

4. DepKes RI. Panduan nasional keselamatan pasien rumah sakit (patient safety). 2nd ed. Jakarta: DepKes Rl; 2008.

5. Peraturan Mentri Kesehatan Republik Indonesia (Permenkes). Keselamatan Pasien Rumah Sakit [internet]. 2011. Available from: http://www.hukor. depkes.go.id/up_prod_permenkes/PMK\%20 No. \% 201691\%20ttg\%20Keselamatan $\% 20$ Pasien\%20Rumah\%20Sakit.pdf

6. Potter PA, Perry AG. Fundamental of nursing fundamental keperawatan. Trans: Nggie AF, Albar M. Ed: Hartanti. 7th ed. Jakarta: Salemba Medika; 2009.

7. Berman A, Snyder S, Kozier B, Erb G. Buku Ajar Praktik Keperawatan Klinis. 5th ed. Penj: Meiliya E, Wahyuningsih E, Yulianti D. Ed: Ariani, F. Jakarta: EGC; 2009.

8. Peraturan Mentri Kesehatan Republik Indonesia (Permenkes) No. 30. Standar Pelayanan Kefarmasian Di Puskesmas. 2014. 